\title{
Who and Why? Requests for Presymptomatic Genetic Testing for Amyotrophic Lateral Sclerosis/Frontotemporal Dementia vs Huntington Disease
}

Maria del Mar Amador, MD, Marcela Gargiulo, PhD, Christilla Boucher, Ariane Herson, Stéphanie Staraci, François Salachas, MD, Fabienne Clot, MD, Cécile Cazeneuve, MD, Isabelle Le Ber, MD, PhD, and Alexandra Durr, MD, PhD

Neurol Genet 2021;7:e538. doi:10.1212/NXG.0000000000000538

\section{Abstract}

\section{Objective}

We aimed to describe the population of subjects seeking presymptomatic counseling for amyotrophic lateral sclerosis and/or frontotemporal dementia (ALS/FTD) and compared them with those demanding the well-established presymptomatic test for Huntington disease (HD).

\section{Methods}

We retrospectively examined the requests of a cohort of individuals at risk of familial ALS/FTD and 1 at risk of $\mathrm{HD}$ over the same time frame of 11 years. The individuals were seen in the referral center of our neurogenetics unit.

\section{Results}

Of the 106 presymptomatic testing (PT) requests from subjects at risk of ALS/FTD, 65\% were seen in the last 3 years. Over two-thirds of the subjects were at risk of carrying mutations responsible for ALS, FTD, or both. Sixty-two percent of the subjects came from families with a known hexanucleotide repeat expansion in C9ORF72. During the same period, we counseled 840 subjects at risk of $\mathrm{HD}$. Subjects at risk of ALS/FTD had the presymptomatic test significantly sooner after being aware of their risk, but were older than those at risk of HD. The youngest subjects requesting the test had the highest disease load in the family $(p<0.05)$.

\section{Conclusions}

Demands for PT for ALS/FTD have been increasingly growing, particularly since the discovery of the C9ORF72 gene. The major specificity of the genetic counseling for these diseases is the unpredictability of the clinical phenotype for most of the genes involved. Awareness of this added uncertainty does not prevent individuals from taking the test, as the dropout rate is not higher than that for HD.

\author{
Correspondence \\ Dr. Durr \\ alexandra.durr@icm-institute.org
}




\section{Glossary}

ALS/FTD = amyotrophic lateral sclerosis and/or frontotemporal dementia; HD = Huntington disease; PT = presymptomatic testing.

The increasing discovery of mendelian genes underlying the familial form of amyotrophic lateral sclerosis (ALS) and frontotemporal dementia (FTD) has substantially enlarged the number of genetic diagnoses of these diseases. ${ }^{1}$ Although only a subset of at-risk individuals request presymptomatic testing (PT), each new diagnosis allows potential access to PT for every adult at risk relative of the newly identified family. Motivations and outcomes for PT are already well known for several late-onset neurologic conditions, such as Huntington disease (HD) and prion diseases, ${ }^{2-5}$ but knowledge of the specific features associated with these neurodegenerative diseases is scarce. These diseases confront clinicians and geneticists with new challenges in the course of presymptomatic, prenatal, and preimplantation testing counseling, particularly given the large phenotypic heterogeneity of many of the genes involved. Here, we aimed to better characterize and understand this selected subgroup of at-risk individuals autonomously requesting PT for ALS/FDT.

ALS is a progressive disorder characterized by the selective degeneration of corticospinal and spinal motor neurons, resulting in progressive paralysis of the 4 limbs, the bulbar region, and the respiratory system, leading to death within an average of 3-5 years after disease onset. With a global incidence of 2/100,000 person-years, the risk of ALS increases after age 40 years, reaching a peak between 65 and 75 years. ${ }^{6}$ Approximately $50 \%$ of patients with ALS present cognitive deficits, with $20 \%$ meeting the clinical criteria of FTD, ${ }^{7}$ the second most frequent degenerative form of presenile dementia after Alzheimer disease. The incidence is estimated between 1.6 and 4/100,000 person-years, with the onset generally between age 45 and 65 years. Frontotemporal degeneration results in changes in behavior, language, and executive functions. ${ }^{8}$ Symptoms related to motoneuron degeneration are found in $15 \%$ of patients with FTD. ${ }^{9}$

Familial forms account for approximately $10 \%$ of ALS cases ${ }^{7}$ and $30 \%-50 \%$ of FTD cases. ${ }^{10}$ ALS and FTD are now considered to belong to the same spectrum, not only because of common clinical traits and the sharing of pathologic features but also due to growing knowledge in the field of genetics, these 2 diseases sharing many causative genes. ${ }^{11}$

The discovery of the hexanucleotide repeat expansion in C9ORF72 in $2011^{12,13}$ was a game changer in the field. It explains approximately $40 \%$ of familial ALS cases, $25 \%$ of familial FTD disease, and 5\%-8\% of apparently sporadic cases. ${ }^{12,14}$ The particularities of genetic counseling for subjects at risk of harboring this expansion have been little explored in detail in the literature. ${ }^{15-17}$
The most extensive experience of our group and others with at-risk individuals and attitudes toward testing has been with $\mathrm{HD}^{2,3,18}$ We have also gained experience from PT for hereditary cerebellar ataxias, ${ }^{19}$ dementias, and prion disease. ${ }^{4}$ The trailblazer role of PT for HD in late-onset diseases is probably explained by its virtually exclusively genetic origin and the not so rare prevalence of the pathological triplet (cytosine, adenine and guanine [CAG]) repeat expansion in the huntingtin gene $\left(\sim 1\right.$ in 568). ${ }^{20}$ In ALS/FTD, the number of the involved genes is unclear. In the case of the most frequently affected gene, C9ORF72, the phenotype of the disease that will develop in the carrier is uncertain, despite efforts to understand the determinants. ${ }^{9}$ Conversely, in $\mathrm{HD}$, the pathologic CAG repeat size in HTT provides an indication of the predicted onset of the disease. Although fallible ${ }^{21}$ and despite the clinical variability of $\mathrm{HD}$, from pure chorea to a purely psychiatric presentation, the individual at risk of $\mathrm{HD}$ can prepare for the phenotype to come. ${ }^{3}$ We expected these differences to lead to a major difference in the process of PT. We thus aimed to examine the first 100 requests of individuals seeking PT who were at risk of carrying a mutation leading to ALS, FTD, or both and to compare them with those demanding PT for HD over the same period.

\section{Methods}

The study included individuals who received genetic counseling in the Neurogenetics Unit of Pitié-Salpêtrière University Hospital (Paris) for being at risk of carrying the mutation known in their family to be responsible for ALS, FTD, or ALS/FTD between 2008 and June 2019. We compared the data obtained with those of the population requesting PT for HD during the same period. This department has gained, over more than 27 years, a vast experience in delivering genetic counseling to subjects at risk of harboring mutations leading to late-onset dominantly inherited neurodegenerative diseases, such as HD, dementias, and prion diseases. At-risk individuals request, on their own initiative, genetic counseling in our clinic. They have been informed about their genetic risk by their affected family member or the neurologist of the affected relative. Genetic counseling takes place in a multidisciplinary framework, comprised of at least a neurologist, geneticist, and psychologist. Interviews are structured as previously reported. ${ }^{22}$ Briefly, at-risk individuals receive from the neurologist/geneticist, before testing, oral and written information about the disease, the genetic risk of transmission, therapeutic implications, and limitations of testing. They are then given time to reflect and make their decision, during which they are supported by at least 1 interview with a 
psychologist of the team. Blood sampling and testing are performed during a later visit. The same neurologist/ geneticist that provided the first information discloses the results. We offer and recommend posttest support and followup to all individuals, regardless of the results of the test. Data retrospectively collected from subjects' medical records, information about their motivation to take the test, and familial disease load of either disease were reviewed.

We calculated a familial disease load score for each individual as follows: each first-degree relative with ALS or FTD scored 1 point, each second-degree relative with ALS or FTD scored 0.5 points, and other more distant relatives with one of these diseases scored 0.1 points. The sum for each individual was used to evaluate the final score of disease load for each phenotype in their families. This score has not been validated and is thus only indicative. Statistical results involving this disease load score should be interpreted with caution.

\section{Standard Protocol Approvals, Registrations, and Consents}

The study of familial ALS or FTD for subjects seen from 2008 to 2017 was approved by local French authorities (Paris Necker ethics committee approval [RBM 02-59 to I.L.B.]). From 2017 to 2019, according to local regulations of Assistance Publique-Hôpitaux de Paris, subjects were informed of their right to object to the publication of their data.

Testing for mutations in the involved genes was performed in the Molecular and Cellular Neurogenetics Department of Pitié-Salpêtrière Hospital (Drs Cazeneuve and Clot). All subjects provided signed informed consent. The laboratory is certified and performs the genetic testing in the routine clinical setting for subjects.

Statistical analyses were performed using SPSS software version 9.1. Quantitative variables are expressed as the mean \pm SD. Frequencies were compared using Pearson $\chi^{2}$ tests or Fisher exact tests, when appropriate, and the means compared using analysis of variance (ANOVA).

\section{Data Availability}

Anonymized data are available from the corresponding author on reasonable request.

\section{Results}

\section{Presymptomatic Testing}

From 2008 to June 2019, 106 subjects, from 78 families, at risk of developing familial ALS or FTD and requesting PT were received in our neurogenetics unit. The demand for predictive testing for these diseases has been steadily increasing (figure), such that over half of the demands were received during the last 3 years $(67 \%, 71 / 106)$. Sixty-one percent of the individuals were women $(65 / 106)$, with a mean age of $42.05 \pm 14.9$ years (18-78). Mutations in the index cases affected 7 different genes (table 1). Most (93/106, 88\%) of the subjects had a 50\% risk a priori of harboring the mutation responsible for the disease. Thirteen individuals (12\%) had a $25 \%$ risk or less because the index case of their family was a second- or further-degree relative. Over two-thirds of the subjects were at risk of carrying mutations responsible for ALS, FTD, or the association of both diseases (C9ORF72 $\mathrm{n}=66$ [50 families], UBQLN2 $\mathrm{n}=5$ [1 family], VCP $\mathrm{n}=3$ [1 family], TBK1 $\mathrm{n}=2$ [1 family). Ten percent of the subjects were exclusively at risk of ALS (SOD1 $\mathrm{n}=8$ [7 families], FUS $\mathrm{n}=3$ [2 families], and $18 \%$ exclusively at risk for FTD $(P G R N \mathrm{n}=11$ [9 families], MAPT $\mathrm{n}=8$ [7 families]). Only 41 individuals (39\%) came to the clinic with a relative or friend.

The main reasons reported for requesting the test were the desire to know their status or to be able to anticipate life decisions $(60 \%, 64 / 106)$, followed by the wish to inform their children of the risk $(18 \%, 19 / 106)$ ( $90 \%$ of the testees' children were adults), or because they wanted to have children $(12 \%, 13 / 106)$. Forty-two percent of the subjects (44/103) came to our clinic to be tested less than 1 year after being informed of their own risk. Individuals with a higher familial disease load, as defined in the methods, were significantly younger when they requested testing (Pearson correlation $0.318, p<0.01)$. There was a significant correlation between the age of the subject at test request and the youngest and oldest ages at disease onset of the cases of the family (Pearson correlation 0.212 and $0.266, p=0.03$ and $p=0.014$ ).

The overall dropout rate was $25 \%$ (26 subjects). Among them, 25 did not undergo blood sampling, and only 1 individual decided not to come to be informed of the available result of the test. Of the 80 subjects who asked for the test results, 35 were carriers of the mutation (table 1). There was no difference in the rate of subjects withdrawing from the testing process according to the disease in their families: ALS vs FTD or ALS and FTD. Individuals not pursuing the testing until the disclosure of results tended to be older (55.3 \pm 9 years vs $49.8 \pm 13$ years, $p=0.05$ ).

Clinical, neurologic, and psychological follow-up of the at-risk individuals is ongoing. To date, there has been no clinical conversion.

Between 2014 and June 2019, our Neurogenetics Laboratory identified 113 pathogenic variants responsible for ALS or ALS/FTD in affected index cases. Although not necessarily issued from the new families, 58 of the here reported PT requests (46 pedigrees) occurred in this same period.

\section{Prenatal Testing}

During the study period 3 of 4 couples at risk of having transmitted the hexanucleotide expansion in C9ORF72 to the fetus in their current pregnancy decided not to undergo prenatal diagnosis, whereas 1 couple did. The fetus was a carrier of the C9ORF72 expansion, and they decided to terminate the pregnancy. Two couples presented for counseling for their risk of transmitting an MAPT mutation. In 1 case, 


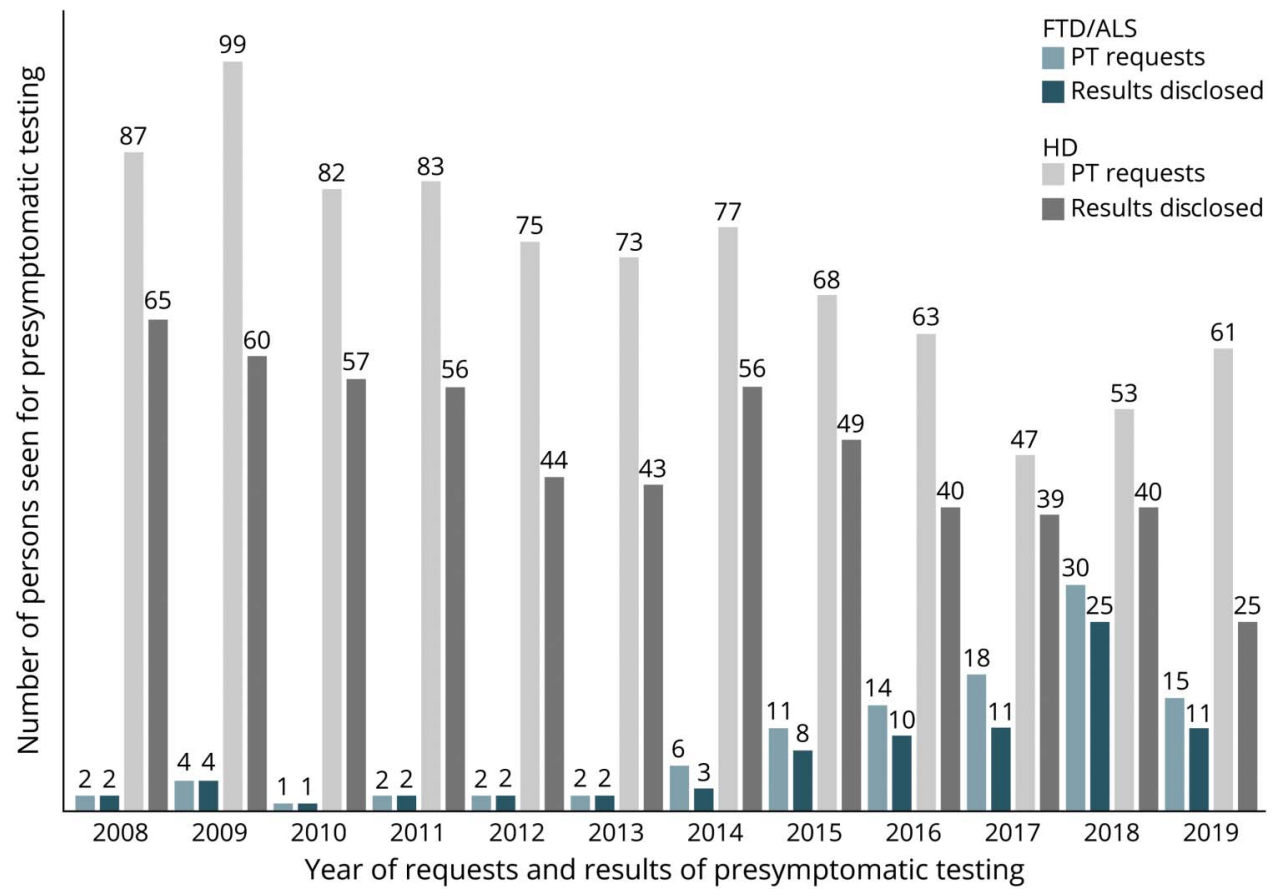

\begin{abstract}
Proportion of testees consulting for presymptomatic testing for ALS/FTD (green) and HD (gray) in a national reference center for rare diseases of the Salpêtriere University Hospital between January 2008 and June 2019. The left bars (light green and light gray) represent the incoming requests, and the dark green and gray bars the disclosures after PT procedures. There was an increasing demand for testing for ALS/FTD and a decreasing demand for $H D$, explained by more widespread offers for testing throughout the country. The proportion of test disclosures was similar for both disease groups, $24 \%$ and $35 \%$, respectively. ALS/FTD = amyotrophic lateral sclerosis and/or frontotemporal dementia; $H D=$ Huntington disease.
\end{abstract}

their motivation for requesting PT was an ongoing pregnancy. They decided to abandon the testing procedure and continue the pregnancy. The other couple, in which the woman was the carrier, requested fetal sex determination for the $\mathrm{X}$-linked $U B Q L N 2$ mutation. One male fetus was terminated, and the subsequent female fetus was carried to term.

\section{Comparison With Subjects at Risk of HD During the Same Time Period}

During the same 11-year period, we received 840 demands by individuals at risk of $\mathrm{HD}$. We were able to compare the 2 disease groups, as a priori risks ( $50 \%$ or $25 \%$ ) of the subjects seeking PT, sex of the subject, sex of the transmitting relative, and dropout rate were not significantly different between HD and ALS/FTD (table 2 ). The subjects requesting $\mathrm{PT}$ for $\mathrm{HD}$ were significantly younger than those at risk of ALS or FTD (HD $35.9 \pm 12.6$ years (18-90) vs ALS/FTD $42.0 \pm 14.9$ years (18-78), $p<0.01)$. Requests for $\mathrm{HD}$ testing occurred significantly later after becoming aware of their own risk than for the group at risk of ALS/FTD, with only $19 \%$ of the subjects at risk of $\mathrm{HD}$ coming to the clinic within the first year (vs 44\% for ALS/FTD; $p<0.01$ ). The reasons reported for seeking the test were not significantly different between the 2 groups. The dropout rate from the test tended to be higher among the subjects seeking PT for HD (34\%) than for ALS/FTD (25\%), although not significantly different.

For prenatal testing, 37 couples at risk of $\mathrm{HD}$ underwent genetic counseling while pregnant, 25 took the presymptomatic test, and 13 were carriers. Among them, 6 underwent prenatal testing. This was not different from ALS/FTD.

\section{Discussion}

In the literature, experience of large cohorts of presymptomatic subjects at risk of ALS/DFT is rare. In 2016, Benatar et al. ${ }^{15}$ published updated guidelines for presymptomatic genetic counseling in ALS, based on their experience with 161 firstdegree relatives at risk participating in a study. Here, we report the uptake and motivation for over 100 presymptomatic individuals at risk of ALS/FTD. There has been a clear increase of requests for testing of at-risk individuals for ALS/FTD in France, especially since 2014, following the larger number of genetic diagnoses for these diseases. The HD cohort was restricted to the same period in which testing for ALS/FTD was available to avoid any bias due to society's perception of genetic testing between the early 90s and after 2008 that could potentially explain the increasing frequency of testing over time. In France, PT is free of charge for all requesting subjects. Furthermore, French law has prohibited companies from considering genetic testing results for insurance purposes since 2005.

Individuals requesting PT for ALS/FTD contacted the neurogenetics clinic sooner after becoming aware of their risk than those requesting the $\mathrm{HD}$ test. The more rapid contact for the ALS/FTD group could be explained by the particularly severe and rapidly progressive phenotype of these diseases, as observed for other rapidly progressing neurodegenerative diseases, such as prion disease. ${ }^{4}$ The risk of a rapidly progressive phenotype may be less bearable over longer periods and create, more than in HD, an urge to seek genetic counseling. Alternatively, some at-risk individuals prefer to be tested 
Table 1 Characteristics of Requests for Predictive Testing According to the Genotype of the Index Case for Individuals at Risk of FTD, ALS, or Both

\begin{tabular}{|c|c|c|c|c|c|c|c|c|c|}
\hline & C9ORF72 & PGRN & MAPT & SOD1 & UBQLN2 & FUS & $V C P$ & TBK1 & $\begin{array}{l}p \\
\text { Value }\end{array}$ \\
\hline Inheritance pattern & $A D$ & $A D$ & $A D$ & $A D$ & X-linked D & $A D$ & $A D$ & $A D$ & - \\
\hline Number $(\%$ of 106$)$ & $66(62 \%)$ & $11(10 \%)$ & $8(8 \%)$ & $8(8 \%)$ & $5(5 \%)$ & $3(3 \%)$ & $3(3 \%)$ & $2(2 \%)$ & - \\
\hline $\begin{array}{l}\text { No. of families } \\
\text { (total = 78) }\end{array}$ & 50 & 9 & 7 & 7 & 1 & 2 & 1 & 1 & - \\
\hline Percent females & $60 \%$ & $46 \%$ & $63 \%$ & $88 \%$ & $60 \%$ & $100 \%$ & $67 \%$ & $50 \%$ & 0.58 \\
\hline $\begin{array}{l}\text { Age at first contact } \\
\text { (in y) }\end{array}$ & $\begin{array}{l}44 \pm 15 \\
(18-78)\end{array}$ & $\begin{array}{l}40 \pm 15 \\
(22-74)\end{array}$ & $\begin{array}{l}35 \pm 11 \\
(21-54)\end{array}$ & $\begin{array}{l}42 \pm 14 \\
(26-67)\end{array}$ & $\begin{array}{l}34 \pm 16 \\
(18-59)\end{array}$ & $\begin{array}{l}31 \pm 19 \\
(19-53)\end{array}$ & $\begin{array}{l}44 \pm 15 \\
(33-61)\end{array}$ & $\begin{array}{l}44 \pm 25 \\
(26-61)\end{array}$ & 0.59 \\
\hline $\begin{array}{l}\text { Asked for test results, } \\
\mathrm{n}(\%)\end{array}$ & $\begin{array}{l}45 / 66 \\
(68 \%)\end{array}$ & $\begin{array}{l}8 / 11 \\
(73 \%)\end{array}$ & $\begin{array}{l}7 / 8 \\
(88 \%)\end{array}$ & $\begin{array}{l}7 / 8 \\
(88 \%)\end{array}$ & $\begin{array}{l}5 / 5 \\
(100 \%)\end{array}$ & $\begin{array}{l}3 / 3 \\
(100 \%)\end{array}$ & $\begin{array}{l}3 / 3 \\
(100 \%)\end{array}$ & $\begin{array}{l}2 / 2 \\
(100 \%)\end{array}$ & 0.39 \\
\hline $\begin{array}{l}\text { Unfavorable results } \\
\text { (no. of carriers) }\end{array}$ & $24 / 45$ & $3 / 8$ & $3 / 7$ & $2 / 7$ & $3 / 5$ & $0 / 3$ & $0 / 3$ & $0 / 2$ & - \\
\hline \multicolumn{10}{|l|}{$\begin{array}{l}\text { Phenotype of the index } \\
\text { case }\end{array}$} \\
\hline FTD, $n$ & $21(32 \%)$ & $11(100 \%)$ & $8(100 \%)$ & 0 & 0 & 0 & $3(100 \%)$ & 0 & $<0.01$ \\
\hline ALS, $n$ & $28(42 \%)$ & 0 & 0 & $8(100 \%)$ & $5(100 \%)$ & $3(100 \%)$ & 0 & $2(100 \%)$ & - \\
\hline FTD-ALS, $n$ & $17(25 \%)$ & 0 & 0 & 0 & 0 & 0 & 0 & 0 & - \\
\hline $\begin{array}{l}\text { Mean familial } \\
\text { disease load score } \\
\text { FTD }\end{array}$ & $\begin{array}{l}0.95 \pm 0.86 \\
(0.0-3.5)\end{array}$ & $\begin{array}{l}2.02 \pm 0.78 \\
(1.0-3.1)\end{array}$ & $\begin{array}{l}2.24 \pm 1.24 \\
(1.0-4.5)\end{array}$ & $0.0 \pm 0.0$ & $0.0 \pm 0.0$ & $0.0 \pm 0.0$ & $\begin{array}{l}2.00 \pm 0.87 \\
(0.0-2.5)\end{array}$ & $0.0 \pm 0.0$ & $<0.01$ \\
\hline $\begin{array}{l}\text { Mean familial } \\
\text { disease load score } \\
\text { ALS }\end{array}$ & $\begin{array}{l}1.02 \pm 0.97 \\
(0.0-4.5)\end{array}$ & $\begin{array}{l}0.0 \pm 0.0 \\
(0.0-0.0)\end{array}$ & $\begin{array}{l}0.25 \pm 0.7 \\
(0.0-2.0)\end{array}$ & $\begin{array}{l}2.75 \pm 1.39 \\
(1.0-5.5)\end{array}$ & $\begin{array}{l}1.70 \pm 0.6 \\
(1.0-2.5)\end{array}$ & $\begin{array}{l}3.17 \pm 0.98 \\
(2.6-4.3)\end{array}$ & $\begin{array}{l}0.0 \pm 0.0 \\
(0.0-0.0)\end{array}$ & $\begin{array}{l}0.8 \pm 3.5 \\
(0.5-1.0)\end{array}$ & $<0.01$ \\
\hline $\begin{array}{l}\text { Minimal age at onset } \\
\text { in family }\end{array}$ & $\begin{array}{l}55 \pm 10 \\
(32-72)\end{array}$ & $\begin{array}{l}56 \pm 8 \\
(47-69)\end{array}$ & $\begin{array}{l}42 \pm 9 \\
(24-48)\end{array}$ & $\begin{array}{l}43 \pm 10 \\
(27-55)\end{array}$ & $\begin{array}{l}20 \pm 0 \\
(20-20)\end{array}$ & $\begin{array}{l}41 \pm 7 \\
(33-45)\end{array}$ & $\begin{array}{l}55 \pm 0 \\
(55-55)\end{array}$ & $\begin{array}{l}58 \pm 0 \\
(58-58)\end{array}$ & $<0.01$ \\
\hline $\begin{array}{l}\text { Maximal age at } \\
\text { onset in family }\end{array}$ & $\begin{array}{l}62 \pm 12 \\
(25-85)\end{array}$ & $\begin{array}{l}59 \pm 0 \\
(59-59)\end{array}$ & $\begin{array}{l}56 \pm 1 \\
(55-56)\end{array}$ & $\begin{array}{l}54 \pm 15 \\
(34-72)\end{array}$ & $\begin{array}{l}30 \pm 0 \\
(30-30)\end{array}$ & $\begin{array}{l}63 \pm 9 \\
(53-68)\end{array}$ & NA & NA & $<0.01$ \\
\hline
\end{tabular}

Abbreviations: $A D=$ autosomal dominant; $D=$ dominant; $n=$ number; $N A=$ not available.

Quantitative variables are expressed as the mean \pm SD.

a See Methods for familial disease load score calculation for each individual. $p$ Values refer to the comparison of frequencies (Pearson $\chi^{2}$ test or Fisher exact test when appropriate) and comparison of the means (ANOVA).

after the death of their relatives, which occurs later in HD. Some at-risk individuals mentioned their preference to undergo their own test once their relatives had died to spare them the suffering of knowing they had transmitted the disease. Further studies are necessary to examine these hypotheses.

The characteristics and attitudes of those requesting testing for ALS/FTD and HD were similar, including during pregnancy. The differences in motivation, with more couples wanting to become parents for $\mathrm{HD}$, could be explained by the younger age of this population and thus the higher number of subjects of childbearing age.

For genes responsible for both phenotypes ALS and FTD, we systematically discussed during the interviews the different prognoses and the consequences for the patients and their relatives of both diseases. Strikingly, we noted that they projected their own risk almost exclusively to the phenotype they knew from their relatives (motor or cognitive), undermining the potential impact of knowledge of the other phenotypes unknown to them. These data, however, were not prospectively collected from the medical records, and thus, statistical analysis was not possible. Further research should explore the testees' knowledge of these complex diseases before and after counseling.

The rate of diagnosis of hereditary ALS and ALS/FTD has been relatively low in Paris during the last 5 years, as our Neurogenetics Laboratory has identified only 113 patients with ALS harboring a pathogenic variant, i.e., with hereditary disease. During the same period, the ALS Clinic of the Salpêtrière Hospital has seen approximately 2,000 new cases of ALS. Statistically and according to the literature, ${ }^{7}$ we expected more than 200 new genetic ALS diagnoses over this time frame. This is likely explained by the reluctance of ALS clinicians to advise genetic counseling, as many believe that no consequence could arise from the knowledge of hereditability 
Table 2 Comparison Between At-Risk Subjects Requesting Presymptomatic Testing for ALS/FTD or HD During the Same Time Period

\begin{tabular}{lll}
\hline & ALS/FTD & HD \\
\hline No. of requests (2008-2019) & 106 & 840 \\
\hline Mean age (in years) & $42.05 \pm 14.9(18-78)$ & $35.9 \pm 12.6$ y (18-90) \\
\hline Women & $61 \%(65)$ & $54 \%(465)$ \\
\hline $\begin{array}{l}\text { Theoretical risk of being a carrier: } \\
\text { 50\% at risk/25\% at risk }\end{array}$ & $88 \%(93) / 12 \%(13)$ & $90 \%(760) / 10 \%(80)$ \\
\hline Mother transmitting the disease & $46 \%(49)$ & $49 \%(413)$ \\
\hline Disclosure/no disclosure & $75 \%(80) / 25 \%(26)$ & $66 \%(558) / 34 \%(282)$ \\
\hline $\begin{array}{l}\text { Recent (<1 year) or longer (>1 year) } \\
\text { knowledge of being at risk }\end{array}$ & $44 \%(45)$ vs 56\% (58); & $19 \%(123)$ vs 80\% (508); \\
\hline Motivation to be tested & NA 3 subjects & NA 209 subjects \\
\hline To know, to be certain & & 0.47 \\
\hline Desire to have children & $49 \%(50)$ & $50 \%(383)$ \\
\hline Inform children about the risk & $13 \%(13)$ & $19 \%(150)$ \\
\hline To anticipate & $18 \%(19)$ & $13 \%(100)$ \\
\hline Don't know & $14 \%(14)$ & $9 \%(67)$ \\
\hline
\end{tabular}

Abbreviation: NA = not available.

$p$ Values refer to the comparison of frequencies (Pearson $\chi^{2}$ test or Fisher exact test when appropriate) and the comparison of means (ANOVA). Quantitative variables are expressed as the mean \pm SD.

on top of a devastating diagnosis and prognosis, other than increased sorrow. During the same period of 5 years, 58 subjects requested PT in our center. Although the at-risk subjects are not necessarily related to the newly identified families, this results in a ratio of genetic PT activity vs genetic diagnostic activity at our center of approximately $1: 2$. This approximation suggests that there is a higher percentage of demands for PT for ALS/FTD than HD.

With a few exceptions, ${ }^{15}$ published studies report low uptake rates of PT among at-risk populations, ranging from $7 \%$ to one-third of the subjects at risk. ${ }^{23}$ Our study suggests that there is a nonnegligible number of demands for PT arising from the relatively rare genetic diagnoses. Familial ALS cases will likely be increasingly sought and recognized in the era of new promising gene-specific treatments for the 2 most common genes in familial ALS: SOD ${ }^{24}$ and C9ORF72 (NCT03626012). The association of an increase in the number of genetic diagnoses and the hope of specific treatment may lead to an increase in the demand for genetic counseling and PT in affected families. The FTD field appears, in particular, to be ahead in the generalization of genetic discussions and the sampling of patients with FTD. We believe that the practices between the ALS and FTD communities should be harmonized. Our study illustrates how virtually the same families may encounter both diseases in most cases.

Despite our efforts to ascertain any potential bias, certain limitations could not be circumvented. First, we collected the data retrospectively. Certain relevant information that was not systematically collected was unfit for analysis. Furthermore, the results all came from a single center under the French legal frame. Finally, the follow-up of testees is ongoing, and thus, the outcome is pending. However, our principal aim was to understand the uptake and interest in ALS/FTD PT on the basis of our experience and contribute to discussion in this field.

In conclusion, requests for PT for ALS and FTD have been progressively growing over the last several years and may continue to do so. The principal feature of the genetic counseling for this group of genes is the unpredictable heterogeneity of the clinical phenotype. An awareness of this added uncertainty does not prevent individuals from having the test, as dropout rates are no higher than for HD. Indeed, this aspect appears to be overlooked by at-risk subjects. Despite the challenges of presymptomatic genetic testing in these diseases, genetic counseling continues to respond to a growing demand that genetic counselors must take into consideration. Further studies are needed to better understand how the process of testing or the knowledge of their genetic status affects the life trajectory of presymptomatic subjects.

\section{Acknowledgment}

The authors are grateful to all participants.

\section{Study Funding}

No targeted funding reported. 


\section{Disclosure}

The authors declare no conflicts of interest. Go to Neurology. org/NG for full disclosures.

\section{Publication History}

Received by Neurology: Genetics July 28, 2020. Accepted in final form October 20, 2020.

Appendix Authors

\begin{tabular}{lll}
\hline Name & Location & Contribution \\
\hline Maria del & Pitié-Salpêtrière & $\begin{array}{l}\text { Design and conceptualization of } \\
\text { the study, data collection and } \\
\text { amalysis, and drafting and revision } \\
\text { of the manuscript for intellectual } \\
\text { content }\end{array}$ \\
\hline
\end{tabular}

\begin{tabular}{|c|c|c|}
\hline $\begin{array}{l}\text { Marcela } \\
\text { Gargiulo, } \\
\text { PhD }\end{array}$ & $\begin{array}{l}\text { Pitié-Salpêtrière } \\
\text { Hospital, Paris, } \\
\text { France }\end{array}$ & $\begin{array}{l}\text { Design and conceptualization of } \\
\text { the study, data collection and } \\
\text { analysis, and drafting and revision } \\
\text { of the manuscript for intellectual } \\
\text { content }\end{array}$ \\
\hline
\end{tabular}

\begin{tabular}{|c|c|c|}
\hline $\begin{array}{l}\text { Christilla } \\
\text { Boucher }\end{array}$ & $\begin{array}{l}\text { Pitié-Salpêtrière } \\
\text { Hospital, Paris, } \\
\text { France }\end{array}$ & $\begin{array}{l}\text { Data collection and analysis and } \\
\text { drafting and revision of the } \\
\text { manuscript }\end{array}$ \\
\hline $\begin{array}{l}\text { Ariane } \\
\text { Herson }\end{array}$ & $\begin{array}{l}\text { Pitié-Salpêtrière } \\
\text { Hospital, Paris, } \\
\text { France }\end{array}$ & $\begin{array}{l}\text { Data collection and analysis and } \\
\text { drafting and revision of the } \\
\text { manuscript }\end{array}$ \\
\hline $\begin{array}{l}\text { Stéphanie } \\
\text { Staraci }\end{array}$ & $\begin{array}{l}\text { Pitié-Salpêtrière } \\
\text { Hospital, Paris, } \\
\text { France }\end{array}$ & $\begin{array}{l}\text { Data collection and analysis and } \\
\text { drafting and revision of the } \\
\text { manuscript }\end{array}$ \\
\hline $\begin{array}{l}\text { François } \\
\text { Salachas, } \\
\text { MD }\end{array}$ & $\begin{array}{l}\text { Pitié-Salpêtrière } \\
\text { Hospital, Paris, } \\
\text { France }\end{array}$ & $\begin{array}{l}\text { Data collection and analysis and } \\
\text { drafting and revision of the } \\
\text { manuscript }\end{array}$ \\
\hline $\begin{array}{l}\text { Fabienne } \\
\text { Clot, MD }\end{array}$ & $\begin{array}{l}\text { Pitié-Salpêtrière } \\
\text { Hospital, Paris, } \\
\text { France }\end{array}$ & $\begin{array}{l}\text { Data collection and analysis and } \\
\text { drafting and revision of the } \\
\text { manuscript }\end{array}$ \\
\hline $\begin{array}{l}\text { Cécile } \\
\text { Cazeneuve, } \\
\text { MD }\end{array}$ & $\begin{array}{l}\text { Pitié-Salpêtrière } \\
\text { Hospital, Paris, } \\
\text { France }\end{array}$ & $\begin{array}{l}\text { Data collection and analysis and } \\
\text { drafting and revision of the } \\
\text { manuscript }\end{array}$ \\
\hline $\begin{array}{l}\text { Isabelle Le } \\
\text { Ber, MD, PhD }\end{array}$ & $\begin{array}{l}\text { Pitié-Salpêtrière } \\
\text { Hospital, Paris, } \\
\text { France }\end{array}$ & $\begin{array}{l}\text { Design and conceptualization of } \\
\text { the study, data collection and } \\
\text { analysis, and drafting and revision } \\
\text { of the manuscript for intellectual } \\
\text { content }\end{array}$ \\
\hline $\begin{array}{l}\text { Alexandra } \\
\text { Durr, MD, } \\
\text { PhD }\end{array}$ & $\begin{array}{l}\text { Pitié-Salpêtrière } \\
\text { Hospital, Paris, } \\
\text { France }\end{array}$ & $\begin{array}{l}\text { Design and conceptualization of } \\
\text { the study, data collection and } \\
\text { analysis, and drafting and revision } \\
\text { of the manuscript for intellectual } \\
\text { content }\end{array}$ \\
\hline
\end{tabular}

\section{References}

1. Nguyen HP, Van Broeckhoven C, van der Zee J. ALS genes in the genomic era and their implications for FTD. Trends Genet 2018;34:404-423.

2. Gargiulo M, Tezenas du Montcel S, Jutras MF, Herson A, Cazeneuve C, Durr A. A liminal stage after predictive testing for Huntington disease. J Med Genet 2017;54: 511-520.

3. Gargiulo M, Lejeune S, Tanguy M-L, et al. Long-term outcome of presymptomatic testing in Huntington disease. Eur J Hum Genet 2009;17:165-171.

4. Schwartz M, Brandel JP, Babonneau ML, et al. Genetic testing in prion disease: psychological consequences of the decisions to know or not to know. Front Genet 2019;10:895.

5. UK Huntington's Disease Prediction Consortium, Baig SS, Strong M, Rosser E, et al. 22 Years of predictive testing for Huntington's disease: the experience of the UK Huntington's Prediction Consortium. Eur J Hum Genet 2016;24: 1396-1402.

6. Logroscino G, Traynor BJ, Hardiman O, et al. Incidence of amyotrophic lateral sclerosis in Europe. J Neurol Neurosurg Psychiatry 2010;81:385-390.

7. Taylor JP, Brown RH, Cleveland DW. Decoding ALS: from genes to mechanism. Nature 2016;539:197-206.

8. Olney NT, Spina S, Miller BL. Frontotemporal dementia. Neurol Clin 2017;35: 339-374.

9. Fournier C, Barbier M, Camuzat A, et al. Relations between C9orf72 expansion size in blood, age at onset, age at collection and transmission across generations in patients and presymptomatic carriers. Neurobiol Aging 2019;74: 234-e8.

10. Seelaar H, Rohrer JD, Pijnenburg YA, Fox NC, van Swieten JC. Clinical, genetic and pathological heterogeneity of frontotemporal dementia: a review. J Neurol Neurosurg Psychiatry 2011;82:476-486.

11. Achi EY, Rudnicki SA. ALS and frontotemporal dysfunction: a review. Neurol Res Int 2012;2012:806306.

12. DeJesus-Hernandez M, Mackenzie IR, Boeve BF, et al. Expanded GGGGCC hexanucleotide repeat in noncoding region of C9ORF72 causes chromosome 9p-linked FTD and ALS. Neuron 2011;72:245-256.

13. Renton AE, Majounie E, Waite A, et al. A hexanucleotide repeat expansion in C9ORF72 is the cause of chromosome 9p21-linked ALS-FTD. Neuron 2011;72: $257-268$.

14. Millecamps S, Boillée S, Le Ber I, et al. Phenotype difference between ALS patients with expanded repeats in C9ORF72 and patients with mutations in other ALS-related genes. J Med Genet 2012;49:258-263.

15. Benatar M, Stanislaw C, Reyes E, et al. Presymptomatic ALS genetic counseling and testing: experience and recommendations. Neurology 2016;86: 2295-2302.

16. Chiò A, Battistini S, Calvo A, et al. Genetic counselling in ALS: facts, uncertainties and clinical suggestions. J Neurol Neurosurg Psychiatry 2014;85:478-485.

17. Fong JC, Karydas AM, Goldman JS. Genetic counseling for FTD/ALS caused by the C9ORF72 hexanucleotide expansion. Alzheimers Res Ther 2012;4:27.

18. Bonnard A, Herson A, Gargiulo M, Durr A. Reverse pre-symptomatic testing for Huntington disease: double disclosure when $25 \%$ at-risk children reveal the genetic status to their parent. Eur J Hum Genet 2019;27:22-27.

19. Goizet C, Lesca G, Dürr A. Presymptomatic testing in Huntington's disease and autosomal dominant cerebellar ataxias. Neurology 2002;59: 1330-1336.

20. Thion MS, Humbert S. Cancer: from wild-type to mutant Huntingtin. J Huntingt Dis 2018;7:201-208.

21. Lee J-M, Correia $\mathrm{K}$, Loupe J, et al. CAG repeat not polyglutamine length determines timing of huntington's disease onset. Cell 2019;178:887-900.e14.

22. Clément S, Gargiulo M, Feingold J, Durr A. Guidelines for presymptomatic testing for Huntington's disease: past, present and future in France. Rev Neurol (Paris) 2015; 171:572-580.

23. Crook A, Williams K, Adams L, Blair I, Rowe DB. Predictive genetic testing for amyotrophic lateral sclerosis and frontotemporal dementia: genetic counselling considerations. Amyotroph Lateral Scler Frontotemporal Degener 2017;18: $475-485$.

24. Miller T, Cudkowicz M, Shaw PJ, et al. Phase 1-2 trial of antisense oligonucleotide tofersen for SOD1 ALS. N Engl J Med 2020;383:109-119. 


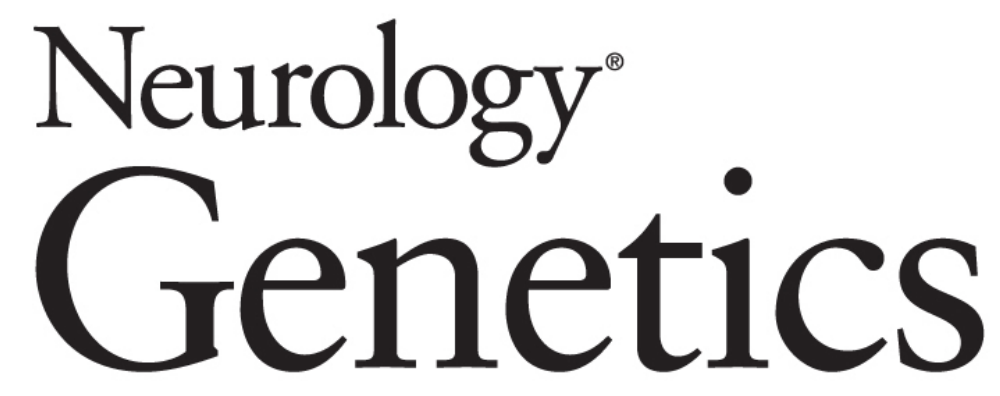
Who and Why? Requests for Presymptomatic Genetic Testing for Amyotrophic Lateral Sclerosis/Frontotemporal Dementia vs Huntington Disease
Maria del Mar Amador, Marcela Gargiulo, Christilla Boucher, et al. Neurol Genet 2021;7;
DOI 10.1212/NXG.0000000000000538

This information is current as of December 24, 2020

Updated Information \& Services

References

Subspecialty Collections

Permissions \& Licensing

Reprints including high resolution figures, can be found at: http://ng.neurology.org/content/7/1/e538.full.html

This article cites 24 articles, 5 of which you can access for free at: http://ng.neurology.org/content/7/1/e538.full.html\#\#ref-list-1

This article, along with others on similar topics, appears in the following collection(s):

All Genetics

http://ng.neurology.org//cgi/collection/all_genetics

Amyotrophic lateral sclerosis

http://ng.neurology.org//cgi/collection/amyotrophic_lateral_sclerosis_ Frontotemporal dementia

http://ng.neurology.org//cgi/collection/frontotemporal_dementia

Huntington's disease

http://ng.neurology.org//cgi/collection/huntingtons_disease

Information about reproducing this article in parts (figures,tables) or in its entirety can be found online at:

http://ng.neurology.org/misc/about.xhtml\#permissions

Information about ordering reprints can be found online:

http://ng.neurology.org/misc/addir.xhtml\#reprintsus

Neurol Genet is an official journal of the American Academy of Neurology. Published since April 2015, it is an open-access, online-only, continuous publication journal. Copyright Copyright @ 2020 The Author(s). Published by Wolters Kluwer Health, Inc. on behalf of the American Academy of Neurology.. All rights reserved. Online ISSN: 2376-7839.

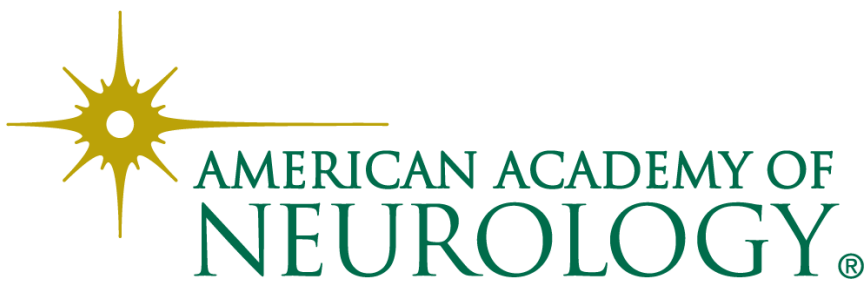

